\title{
Investigating Pre-Service English Teachers' Perception on the Use of Multimedia in EFL Teaching and Learning Process: Pedagogical Implication
}

\author{
Didih Faridah \\ Universitas Galuh Ciamis, Indonesia \\ didihfaridah@gmail.com \\ Leni Irianti \\ Universitas Galuh Ciamis, Indonesia \\ bulen.lenie@gmail.com \\ Reska Laila Fachriyani \\ Universitas Galuh Ciamis, Indonesia \\ lailareska6@gmail.com
}

\begin{abstract}
This paper reports on investigating pre-service English teachers' perceptions on the use of multimedia in EFL teaching and learning process: pedagogically implication. This research aimed to investigate the pre-service English teachers' perception toward the use of multimedia in EFL teaching and learning process and to observe kind of multimedia are used by the pre-service English teachers' in EFL teaching and learning process. The participant of this research was the 63 senior students of English Department Galuh University. The questionnaire and interview were the instruments used in this research to collect the data. Survey monkey application was used in analyzing the questionnaire by displaying it into the figure and data interpretation based on the answer from a close-ended questionnaire, while the data from telephone interviews were analyzed by displaying data interpretation from the interviewees. After having the findings, the research showed that the students had a positive attitude towards multimedia. Most of the participants agreed that they like multimedia because it helped them in the teaching and learning process. In this era, we can easily found multimedia. PowerPoint, YouTube Videos, Podcast, Canva, PowToon, Picture, CALL, MALL, Digital Comic, Song, PowToon, and Movie are some the kinds of multimedia that can be used by pre-service English teachers' as the solution to make the learning process more interesting and enhance the students' language pedagogy. This research concludes that using multimedia in the teaching and learning process was important to improve their achievements, understanding, performances, and to achieve objectives of language pedagogy.
\end{abstract}

Keywords: Pre-service English teachers', perceptions, multimedia

\section{A. Introduction}

One of the most important factors influencing the success of students is a teacher. The most important role of a teacher in the school is to guide students. Nowadays a teacher has become a guide of students throughout the learning process. A teaching 
Page: $209-222$

situation can be overwhelming, the teacher must not only have a good knowledge of the lesson in hand but also some communication skills such as the ability to observe, supervise, lead a discussion and pose questions (Otsupius, 2014; Syafryadin, 2020). One way to achieve that skill is to be a creative, innovative, and interactive teacher. Multimedia plays an important role for a teacher to help students understand English as a foreign language. As recommended by Richard and Rodgers (1986, p. 87) cited in Regina (2016, p. 65) that students are supposed to study a second language enjoyable. It means the role of the teacher is very important in motivating the students' interest in the English teaching-learning process and also in maintaining the relationship between the teacher and students. Applying multimedia into teaching, the communication of the information becomes an effective instructional medium for delivering information. Interactive learning multimedia could give good effects on cognitive load on teaching, training, and learning. Students can gain much information at once from multimedia (Mishra, S Sharma, 2008). The innovative multimedia can be used by pre-service English teachers' in the EFL teaching-learning process to the young learners such as audio Multimedia, visual Multimedia, audio-visual Multimedia, and the teacher herself as a model (Azwandi, et al. 2020; Anggitasari, et a. 2020, Handayani, et al. 2020; Syahrial \& Syafryadin, 2020).

Several previous studies about the use of multimedia. The first, previous study was conducted by Thamarana (2016) entitled "Use of Multimedia Technologies in English Language Learning: A Study”. The second, previous study was conducted by Sousa et al. (2017) entitled "The effect of multimedia use on the teaching and learning of Social Sciences at tertiary level: A case study". The last, previous study was conducted by Omodora et al. (2014) entitled, "Relevance of educational media and multimedia technology for effective service delivery in teaching and learning processes" Their research showed about use of multimedia which related to English as a second or foreign language. Furthermore, we go deeper into a kinds of multimedia, but some articles discuss kinds of multimedia used in the teaching-learning process, but are not complete and do not include pre-service English teachers' perceptions about the use of multimedia in EFL teaching and learning process.

Based on the explanation previously, the present study was conducted to investigate the pre-service English teachers' perception toward the use of multimedia in 
EFL teaching and learning process and to observe kind of multimedia are used by the pre-service English teachers' in EFL teaching and learning process. Two research questions were formulated as follows:

a. What are the pre-service English teachers' perceptions toward the use of multimedia in EFL teaching and learning process?

b. What kind of multimedia are used by the pre-service English teachers' in EFL teaching and learning process?

\section{B. Theoretical Framework}

\section{Pre-Service English Teachers'}

The pre-service teacher may construct a new identity or transform her or his identity, adapt personal understanding to realities, and decide how to express herself or himself in classroom activity during this teaching practice program (Rodgers \& Scott, 2005). It means that pre-service English teachers are given the task to carry out learning activities in the classroom, which starts from the preparation of learning, the implementation of learning to the evaluation of learning. In other words, a pre-service English teacher is someone who follows a program that pre-empts application capability and is integrated from a previous learning experience into a training program in the form of performance in a matter relating to the teaching position both teaching activities and other task assignments.

\section{Perceptions}

Perception has sometimes been defined as the consciousness of particular material things present to sense. Perception is the process by which an organism receives certain information about the environment (Febrianara, 2015). Perception is a process by which people organize and interpret the patterns of stimuli in the environment (Atkinson \& Adolphs, 2005). Perception means a step to understand the concept of information. From the environment, the received information is called the process of perception. In other words, the process of receiving information is received by the perception of the surrounding information. 


\section{Multimedia in the teaching and learning process}

1. Definition multimedia

According to Hofstetter (2001) cited in (Noor et al., 2009) multimedia is the use of the computer to present and combine text, graphics, audio, and video with links and tools that let the user navigate, interact, create and communicate. However, Vaughan (2008) proposes multimedia as "any combination of text, art, sound, animation, and video delivered to the users by computer or other electronic or digitally manipulated mean." According to those definitions, it can be concluded that multimedia is a combination of some elements of media. Multimedia are very important for the teacher to help students in understanding English as a foreign language in the teaching and learning process.

2. Kinds of multimedia used for teaching and learning process

There are kinds of multimedia used for the teaching and learning process. According to (Zaim \& Hum, 2016), teachers must prepare the target language audiovisual material containing a range of different interaction types to enhance awareness of the verbal and non-verbal features used by members of the speech community. In the following, the kinds of multimedia used for the teaching and learning process will be explained.

a. Kinds of multimedia in speaking skills

Speaking is considered as one of the important skills in learning English. According to (Richards, 1997), there are three functions of speaking skills; interaction, transaction, and performance function. Interaction refers to the conversation. Transaction refers to a situation where the focus is on what is said or done in obtaining goods or services. Performance refers to public talk which transmits information to audiences, such as public announcements and speeches. The kinds of multimedia that can be used for speaking skills such as YouTube, animation videos, films, etc.

b. Kinds of Multimedia in listening skills

Listening skill is language skill where the listener listens to the speaker to receive, interpret, and understanding the information. with multimedia, students can not only hear audio recordings, but they can watch audio-visual media, such as TV news, movies, videos, which contain sound and images. The kinds of multimedia that can be used for listening skills such as exe-learning, YouTube, and Podcast. One of the software that can be used for developing multimedia for listening skills is exe learning Available at https://ejournal.karinosseff.org/index.php/jadila/ 
(Zaim \& Hum, 2016). In addition, YouTube is being increasingly used by teachers to teach the English language as it offers fun and fast access to instruction, culture-based videos, and languages from all over the world (Duffy, 2008). In addition, (Shahid \& Ali, 2018) affirmed that video-podcasts are useful resources for enhancing EFL listening comprehension. Identically, multimedia helps the teachers for developing students' listening skills.

c. Kinds of multimedia in writing skills

Writing is seen as a process, it focuses on the various stages that any process of writing foes through, such as putting ideas down on paper to transform thoughts into words (Brown, 1994). The types of multimedia that can be used for writing skills such as Canva, picture series, animated videos, films, etc. According to (Mukarromah, 2019), Canva is the one application that provided for the user around the world. The students' have new ways or a new method by using this application, so the students more interesting and not only to improve their writing skill but the other benefit they can more creative by making their design that relate with their task. For example, they can use Canva for making a story about their past experiences, so they can add the feature that related to their experience by adding the picture or diagram or something else. Besides using those ways in teaching writing English, One of the other is PowToon. PowToon is an online service to create an exposure that has very interesting animated features including handwriting animation, cartoon animation, transition effects, and more vibrant as well as setting a very easy timeline (Buchori \& Cintang, 2018). Almost all features can be accessed on one screen in the process of making an exposure. The exposure that has built-in cartoon characters, animation models, and objects other cartoons make this service suitable for making instructional media, especially for those students who like the relaxing and informal atmosphere in the classroom. By using animation models and cartoon characters in PowToon, it helps the students to be more creative and imaginative in developing paragraph.

\section{d. Kinds of multimedia in reading skill}

Reading skill is language skill to understand the information conveyed in written form. There are two possible multimedia used for reading comprehension; static visualization and dynamic visualization (Zaim \& Hum, 2016). Static or fixed visualization is a graphic, diagram, and pictures, and dynamic visualization a kind of Available at https://ejournal.karinosseff.org/index.php/jadila/ 
instructional animation. An example of visualization is an illustration in textbook-based instructions or animations in computer-based instruction. The animation is an application which generates a series of the frame so that each frame appears as an alteration of the previous one and where the sequence of frames is determined by the designer or the user (Niknejad \& Rahbar, 2015). Concerning the role of visualization, research has revealed the superiority of animated visualization over static visualization.

\section{Research Methodology}

Related to the research questions and research purposes, the researcher conducted a survey design. Kasunic (2005, p. 3-4) argues that a survey is a data gathering and analysis approach in which respondents answer a question or respond to statements that are developed in advance. According to Cohen and Manion (2018), as cited in Nunan (1992, p.140) and (Maryam, et al., 2019), surveys are the most commonly used descriptive method in educational research and can vary in scope from large-scale government investigations to small-scale studies which conducted by a single researcher. In this research, the researcher focuses on a survey about investigating preservice English teachers' perceptions on the use of multimedia in the teaching and learning process. The total number of the population are 63 people.

The researcher used a questionnaire and an interview as the data collection instruments. The questionnaire was used for gathering the data from the first research question which is looking for Pre-Service English Teachers' Perception on the Use of Multimedia in EFL Teaching and Learning Process. Questionnaires are any written instruments that present respondents with a series of questions or statements to which they are to react either by writing out their answers or selecting from among existing answers (Brown, 2001). In this research, the researcher made the online questionnaire using survey monkey application because the spread of the coronavirus (COVID-19) is still a hot issue in the international world, including in Indonesia. Thus researchers can't take the data directly. Using an online questionnaire was more beneficial because it was effective and efficient in the form of time and budget. This idea was supported by Bandilla et al. (2003) as cited in Rynolds et al. (2007, p. 44) they stated that online (web-based) questionnaires provide several advantages over traditional survey methods in terms of cost, speed, appearance, flexibility, functionality, and usability. In this research, the researcher used a close-ended questionnaire to get quantitative data. The 
Iadila: Iournal of Develonment and Innovation

F-ISSN: 2723-6900

in Ianouago and Iiterature Fducation

P-ISSN: 2745-9578

Publisher: Yayasan Karinosseff Muda Indonesia

Volume 1 Number 2, 2020

Page: $209-222$

closed-ended questions were 9 items adopted from Thamarana (2018). Then, the results showed in the tables and the researcher interpreted it.

The next instrument the researcher used a telephone interview. In the telephone interview, researchers recorded participants' comments to questions about the instrument through telephone. The interview questions were 5 items adapted from (Darwis, 2016). The interview was done to gather from the second research question which is looking at the kinds of multimedia that are used in the teaching and learning process.

\section{Findings and Discussion}

Firstly, the researcher discussed the result of the research based on the data from the close-ended questionnaire. Sixty-three respondents filled the close-ended questionnaire which consisted of nine statements. The questionnaire aimed to investigate the pre-service English teachers' perception toward the use of multimedia in EFL teaching and learning process. The responses of the pre-service English teachers' are as follows:

\begin{tabular}{|c|c|c|c|c|c|c|}
\hline \multirow{2}{*}{ No } & \multirow{2}{*}{ Statements } & \multicolumn{5}{|c|}{ Answer } \\
\hline & & $\mathbf{S A}$ & $\mathbf{A}$ & $\mathbf{N}$ & D & SD \\
\hline 1 & $\begin{array}{l}\text { I feel comfortable with the idea of using multimedia as a } \\
\text { learning tool in English. }\end{array}$ & 32 & 31 & 0 & 0 & 0 \\
\hline 2. & $\begin{array}{l}\text { The use of Animations as a teaching and learning tool in } \\
\text { English excites me. }\end{array}$ & 18 & 24 & 19 & 2 & 0 \\
\hline 3. & $\begin{array}{l}\text { The video player is a valuable teaching and learning tool } \\
\text { for students. }\end{array}$ & 12 & 14 & 19 & 1 & 0 \\
\hline 4. & $\begin{array}{l}\text { Learning speaking by using YouTube videos makes me } \\
\text { get more understand the material. }\end{array}$ & 14 & 28 & 17 & 3 & 1 \\
\hline 5. & $\begin{array}{l}\text { The learning with the use of graphic and E-book are } \\
\text { more useful than the traditional way of learning. }\end{array}$ & 3 & 21 & 33 & 5 & 1 \\
\hline 6. & $\begin{array}{l}\text { The idea of using CALL and MALL application in } \\
\text { teaching and learning English makes me confident. }\end{array}$ & 13 & 30 & 20 & 0 & 0 \\
\hline 7. & $\begin{array}{l}\text { The use of multimedia will change the way I learn and } \\
\text { teach. }\end{array}$ & 14 & 37 & 11 & 1 & 0 \\
\hline 8. & $\begin{array}{l}\text { The use of multimedia helps me understand the concept } \\
\text { in more effective ways. }\end{array}$ & 14 & 38 & 11 & 0 & 0 \\
\hline 9. & $\begin{array}{l}\text { The multimedia helps students learn because it allows us } \\
\text { to express our thinking in better and different ways. }\end{array}$ & 6 & 43 & 13 & 1 & 0 \\
\hline
\end{tabular}


Based on the result of the data analysis from the questionnaire response that was presented in the tables previously, the data showed that pre-service English teachers gave various responses to the use of multimedia in the EFL teaching and learning process. However, all of the pre-service English teachers' of the research perceived the use of multimedia in a positive way. The pre-service English teachers agree that multimedia can help students to improve their understanding of the lessons and also help the teacher as a facilitator to explain the material more interestingly by using multimedia. Multimedia creates a classroom atmosphere that will support the teaching and learning process of the 21st century. According to Hwee et al. (2016), stated that 21 st-century learning is characterized by students ability in developing social skills for collaboration, conflict resolution, and multicultural communication, cognitive skills to engage in critical thinking for innovation and complex problem solving, metacognitive skills to engage in self-reflection and self-learning, productivity skills to organize work effectively and efficiently, and technological skills to exploit ICT tools appropriately. Thus, pre-service English teachers should be able to develop the ability to creatively use technology to meet students' learning needs cause pre-service English teachers should integrate technologies with content and pedagogy. Some of the respondents think that multimedia will motivate them in teaching-learning process, Multimedia should be a supplement to help the students to gain more creativity to learn and they believe that without media in the teaching and learning process it will be boring, to overcome this situation, my performance in transferring knowledge should be helped by suitable media. It is supported by Liu et al. (2009) cited in Wei et al. (2014), using multimedia technology in education can enhance students' problem-solving skills and motivate students to learn. Multimedia in language teaching is to promote students' motivation and learning interest (Patel, 2013).

The pre-service English teacher perceptions towards multimedia in teaching and learning process indicated that the multimedia helped students to have better in learning and teaching process, to gain more creativity to learn and allows teachers to create and share materials to support students' learning as well as to provide learning tasks to help them in practicing the language. It would help them to achieve better performance in learning when the students enjoyed the learning. Students can do whatever they want as long as they get various knowledge to reach the learning objective and besides being able to make the class more interesting it can express the learning material totally and 
helping pre-service English teachers build up a new atmosphere in the teaching and learning process. Thus, Multimedia technologies play a great role in EFL teaching and learning process.

Secondly, the researcher discussed the result of the research based on the data from the interview. The researcher has interviewed and gained the data from the semistructured interview to observe kind of multimedia are used by the pre-service English teachers' in EFL teaching and learning process. In this section, there were 15 students. The data showed that there is a lot of multimedia that can be used in the teaching and learning process. The pre-service English teacher asserts that we can use multimedia depend on the material which will deliver in the teaching and learning process. preservice English teachers used several Multimedia from each variable of Multimedia that could be interpreted as follow: 1) PowerPoint is very simple because they are similar to those in Microsoft Word. In this way, the students can create an instruction of language without studying this program previously. Using PowerPoint in writing and reading class can improve the students' motivation, increasing authentic materials for study, encouraging interaction between the teacher and the students, and also It is helpful when the pre-service English teacher tried to point out learning objectives and write an unfamiliar English word. In line with that, (Hashemi et al., 2012) stated that PowerPoint can enhance your teaching sessions by providing a roadmap, reinforcing what you say, and allowing you to use graphics and other multimedia to clarify understanding and to support different learning styles. 2) Using the Internet in teaching and learning process they can know about how to use resources efficiently to help the learning process, how they enrich educational resources for collaboration, how teachers check the efficiency of resources, and sharing of experience. According to (Geladze, 2015) that using computers and the Internet makes the learning process more interesting and diverse and leads to an increase in cognitive activity. 3) Using PowToon in writing courses, the researcher expected that it would help the lecturers in creating an attractive audiovisual media that could attract the students' attention. For example, the pre-service English teachers' could add materials in the form of video. The students are not only watching the video, but they also can observe the materials presented indirectly. PowToon is an audiovisual media that can help the students to increase their achievement in writing 
(Yuniari, 2018). 4) YouTube has become one of the most popular websites in the world. The use of YouTube as a learning media in the speaking class can help students to improve their speaking skills (Kurniawan, 2018). It is considered a source of online material that has a significant role in language teaching and learning. It also provides students with everyday language videos and authentic live situations that could help them improve their understanding, performance, and production of the teaching and learning process. 5) Using Podcast helped the students in the listening course, the clear native pronunciation derived from Podcast engaged their interest and made learning more exciting. However, students can face many problems such as too long Podcasts or the availability of internet access. Podcasts are useful resources for enhancing EFL listening comprehension (Shahid \& Ali, 2018). 6) Pictures are a kind of multimedia that can help the EFL English teacher. A picture is used by the teacher to stimulate student memory, can make the students interest in the lesson, and motivate them in the teaching and learning process. If the students are motivated they will participate actively and will learn hard during a teaching-learning process. The use of pictures could give an enjoyable situation in teaching and learning activity, as the students do not get bored in having an English class. The implementation of using picture series has beneficial effects in teaching reading comprehension (Hendra et al. 2017). It could make the teaching-learning activities run well. 7) A movie is one of the multimedia that can be used in the teaching and learning process. According to (Sufen, 2006), movies provide both audio and visual materials that help students understand the language more easily. When watching a movie, students not only listen to the characters but also watch their movements and students seem to almost interact with the activities in the movies. Furthermore, in a movie class, they tend to learn naturally so they pick up the language spontaneously. For many students, movies are much more attractive, interesting, and impressive than common material printed in books or audible material in tape, because of the visual nature and immediacy of the medium (Fata et al., 2016). 8) Music is one of the most effective ways of influencing the emotional behavior of students because they perceive singing, not as an educational process, but rather as a game or an activity for relaxation. Such activities not only completely change the atmosphere of the lesson but also contribute to the unconscious recognition of new words and expressions. According 
to Kuśnierek, A. (2016, p. 24) believes that "people usually identify songs with fun, which is why learning through songs is associated with an enjoyable experience. Moreover, music may be used to relax students since for many learning a new language is a new experience". 9) Digital Comics are interesting for all students. Using a digital comic is not only fun but also allows students to design texts according to their personalities and aesthetic values. For instance, students can choose the characters and the background that they like most, to create the most personally engaging comic strips. Digital comics are easy to use and capable of encouraging students to write creatively (Salehi, 2012).

The result of this study agrees with Hismanoglu (2012) indicated that bringing technology in the classroom helps both teachers and learners to create a good learning environment to enhance the teaching and learning processes. The use of Multimedia technologies in teaching the English language is one of the best recent and technological approaches in language learning, especially to inculcate and strengthen the opportunities to achieve objectives of language pedagogy (Thamarana, 2016).

Summing up, based on the questionnaire and interview, all of the pre-service English teachers feel that multimedia is very important for them. Most of them stated that without multimedia in the teaching and learning process, Learning will not be carried out well.

\section{E. Conclusions}

The pre-service English teachers' participated in the study perceive that using multimedia in the teaching and learning process is effective since it saves effort and makes the class more attractive. Besides, pre-service English teachers assume that the use of multimedia can help them in practicing their language skills. They also argue that they feel multimedia can stimulates students' interest and engages them in new learning experiences.

There are a lot of Multimedia that can be used by the pre-service English teachers in the learning process, but there were not all of the multimedia used by the pre-service English teachers. Based on the data obtained from the telephone interview that the preservice English teachers' said we can use multimedia depends on the material or context Available at https://ejournal.karinosseff.org/index.php/jadila/ 
Page: 209-222

which will deliver to the students or as needed for the material or the lesson. They suggest several Multimedia that could be interpreted as follow: PowerPoint, YouTube Videos, Podcast, Canva, PowToon, Picture, CALL, MALL, Digital Comic, Song, PowToon, and Movie.

Multimedia can help to improve the students' focus caused multimedia allows integration of text, graphics, audio, and video in a range of combinations. This text, graphics, audio, and video can help the pre-service English teacher improvisational, interactive with the students' and using multimedia shows students' enthusiasm and interest in learning. Thus, Multimedia supports teaching English as a foreign language.

Based on the data mentioned previously, the close-ended questionnaire and interview showed that forty-six respondents $(73,89 \%$ or a most of the respondents) the pre-service English teachers believed that multimedia make easy to deliver materials in support students' learning as well as possible, allowed them to have better interactivity with the learning modules, improve their performances, and helping them as a preservice English teacher build up a new atmosphere in the teaching and learning process.

\section{References}

Anggitasari, M., Tarwana, W., Febriani, R. B., \& Syafryadin, S. (2020). Using Wattpad to Promote the Students' Responses to Literary Works: EFL College Students' Perspectives and Experiences of Enjoying Short Stories. Jadila: Journal of Development and Innovation in Language and Literature Education, 1(2), 182192.

Atkinson, A. P., \& Adolphs, R. (2005). Visual emotion perception: Mechanisms and processes. Emotion and Consciousness, July, 150-184.

Azwandi, A., Harahap, A., \& Syafryadin, S. (2019). Penyuluhan dan pelatihan ictenhanced teaching-learning sebagai model pengembangan profesional guru di kota Bengkulu. Jurnal Pengabdian Masyarakat Ilmu Terapan (JPMIT), 1(1).

Buchori, A., \& Cintang, N. (2018). The Influence of powtoon-assisted group to group exchange and powtoon-assisted talking chips learning models in primary schools. International Journal of Evaluation and Research in Education (IJERE) 7(3), 221-228. https://doi.org/10.11591/ijere.v7.i3.pp221-228

Darwis, R. (2016). Students ' perceptions towards the use of podcast in learning English : A case study of the second grade students at one high school in Bandung. E- Journal on English Education. 4(2), 80-100.

Duffy, P. (2008). Engaging the YouTube Google-Eyed Generation: Strategies for Using Web 2. 0 in Teaching and Learning. Electronic Journal of e-Learning. 6(2), 119-130.

Febrianara, Y. (2015). Students' perception of the implementation of scaffolding in public speaking class. Yogyakarta: 
Iadila: Iournal of Develonment and Innovation

F-ISSN: 2723-6900

in Ianouaso and I itorature F.ducation

Publisher: Yayasan Karinosseff Muda Indonesia

P-ISSN: 2745-9578

Volume 1 Number 2, 2020

Page: 209-222

Geladze, D. (2015). Using the internet and computer technologies in learning / teaching process. Journal of Education and Practice. 6(2), 67-70.

Handayani, S., Youlia, L., Febriani, R.B., Syafryadin, S. (2020). The use of digital literature in teaching reading narrative text. Journal Of English Teaching, Applied Linguistics And Literatures (JETALL). 3(2), 65-74.

Hashemi, M., Azizinezhad, M., \& Farokhi, M. (2012). Social and PowerPoint as an innovative tool for teaching and learning in modern classes. Procedia - Social and Behavioral Sciences https://doi.org/10.1016/j.sbspro.2011.12.103

Hendra, L. N., Ed, M., \& Supriusman, D. (2017). The Effect of Using Picture Series on Reading Comprehension of the Second Year Students. 1-11.

Hismanoglu, M. (2012). Social and The impact of globalization and information technology on language education policy in Turkey. Procedia - Social and Behavioral Sciences 31, 629-633. https://doi.org/10.1016/j.sbspro.2011.12.115

Maryam, I.S., Febriani, R.B., Kurnia, A.D. (2019). EFL Learners' Perceptions of their Self-Efficacy in Learning Public Speaking Course. Journal of English Education and Teaching. 3(3), 377-391.

Mishra, S Sharma, R. (2008). Interactive multimedia in education and teaching. In Multimedia Technologies: Concepts, Methodologies, Tools, and Applications. 1(2), https://doi.org/10.4018/978-1-59904-953-3.ch062

Mukarromah, L. (n.d.). Improving the Students' Writing Skills through Canva Application. 170102031335.

Niknejad, S., \& Rahbar, B. (2015). Comprehension through visualization : The case of reading comprehension of multimedia-based texts. International Journal of Educational Investigations. 2(5), 144-151.

Noor, W., Wan, H., \& Jusoff, K. (2009). Using multimedia in teaching Islamic studies. Journal Media and Communication Studies. 1(5), 86-94.

Omodora, E. O. D. M., \& Ed, A. E. I. M. (2014). The relevance of Educational Media and Multimedia Technology for Effective Service Delivery in Teaching and Learning Processes. IOSR Journal of Research \& Method in Education (IOSRJRME) 4(2), 48-51.

Otsupius, I. (2014). Micro-Teaching: A Technique for Effective Teaching. African Research Review, 8(4), 183. https://doi.org/10.4314/afrrev.v8i4.15

Patel, C. (2013). Use of Multimedia Technology in Teaching and Learning communication skills: An Analysis. 2(7), 116-123.

Regina, R. (2016). The Used of Multimedia in English Language Teaching; (A Case Study at Smp Negeri 2 Mesjid Raya, Aceh Besar). Journal GEEJ (Getsempena English Education Jurnal. 64-79.

Richards, J. C. (1997). Developing Classroom Speaking Activities; From Theory to Practice. $1-10$.

Rodgers, C. R., \& Scott, K. H. (2005). 40 The development of the personal self and professional identity in learning to teach.

Salehi, H. (2012). Effects of Using Digital Comics to Improve ESL Writing Effects of Using Digital Comics to Improve ESL Writing. Research Journal of Applied Sciences, Engineering and Technology 4(18). 3462-3469

Shahid, S. H., \& Ali, Z. (2018). Finding the Best Length of Video-Podcasts : Effects of Varied numbers of Video-Podcast Used on Listening Comprehension of Saudi Undergraduates. International Journal of Novel Research in Education and 
Learning. 4(5), 19-31.

Sousa, L. De, Richter, B., \& Nel, C. (2017). The effect of multimedia uses on the teaching and learning of Social Sciences at the tertiary level: A case study. Yesterday \& Today. 17, 1-22.

Sufen, H. (2006). On Teaching Non-English Majors Listening and Speaking Through Videos. CELEA Journal, 29(2), 2-8. celea.org.cn

Syafryadin, S. (2020). Students' Strategies in Learning Speaking: Experience of Two Indonesian Schools. Vision: Journal for Language and Foreign Language Learning, 9(1), 33-46.

Thamarana, S. (2016). Use of Multimedia Technologies in English Language Learning A Study. International Journal of English Language Teaching. 4(8), 15-30.

Vaughan, T. (2008). Multimedia: making it work. NY: Osborne Mc Graw-Hill.

Wei, Y., Mai, N., \& Tse-kian, N. (2014). Impact of Learner-Centred Teaching Environment with the Use of Multimedia-mediated Learning Modules in Improving Learning Experience. Jurnal Teknologi, 2, 65-71.

Yuniari, N. M. (2018). The Effect of Using Powtoon Audiovisual Media Upon the Students 'Writing Achievement of the Third Semester Students. Widya Accarya. 9(2). 96.

Zaim, P. M., \& Hum, M. (2016). The Power of Multimedia to Enhance Learn Ers ' Language Skills in Multilingual Class. Proceedings of ISELT FBS Universitas Negeri Padang. 4(1). 22-29. 